M, Beltrão M, Lira SA, Heym KM, Clausen BE, Bigley V, Collin M, Manz MG, McClain $\mathrm{K}$, Merad M, Allen CE. BRAF-V600E expression in precursor versus differentiated dendritic cells defines clinically distinct LCH risk groups. J Exp Med 2014;211:669-683.

14. Nelson DS, Quispel W, Badalian-Very $G$, van Halteren $A G$, van den Bos C, Bovée JV, Tian SY, Van Hummelen P, Ducar M, MacConaill LE, Egeler RM, Rollins BJ. Somatic activating ARAF mutations in Langerhans cell histiocytosis. Blood 2014;123:3152-3155.
15. Brown NA, Furtado LV, Betz BL, Kiel MJ, Weigelin HC, Lim MS, ElenitobaJohnson KS. High prevalence of somatic MAP2K1 mutations in BRAF V600E-negative Langerhans cell histiocytosis. Blood 2014;124:1655-1658.

16. Hirsh R, Giri D, Griffith R, Stone R, Ready N. Langerhans cell histiocytosis following acute leukemia in an adult. Am J Hematol 2009;84:693-694.

17. Xu G, Yang M, Huang J, Jin J. Successful treatment of a case of acute myeloid leukemia following Langerhans cell histiocytosis in an adolescent: a case report and review of the literature. Int J Clin Exp Med 2015;8:3024-3026.

๑Copyright 2019 by Turkish Society of Hematology

Turkish Journal of Hematology, Published by Galenos Publishing House

\title{
Breast Implant-Associated Anaplastic Large-Cell Lymphoma: A Case Report
}

\author{
Meme Implantı ile Illişkili Anaplastik Büyük Hücreli Lenfoma: Olgu Sunumu
}

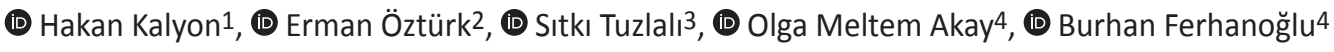 \\ ${ }^{1}$ American Hospital, Clinic of Hematology, istanbul, Turkey \\ ${ }^{2}$ Medeniyet University Faculty of Medicine, Department of Hematology, Istanbul, Turkey \\ ${ }^{3}$ Tuzlalı Pathology Laboratories, Istanbul, Turkey \\ ${ }^{4}$ Koç University Faculty of Medicine, Department of Hematology, Istanbul, Turkey
}

To the Editor,

Breast implant-associated anaplastic large-cell lymphoma (BIA-ALCL) is a rare type of peripheral T-cell lymphoma, also recognized as a specific disease in the 2016 revision of the World Health Organization classification of tumors of the hematopoietic and lymphoid tissues [1]. Although BIA-ALCL has an indolent course, infiltrative forms may be life-threatening and 9 deaths have been reported [2]. The annual incidence is estimated as 0.1 to 0.3 per 100,000 women with implants [3]. The median age is 53 , with the disease being detected after a median of 8 years following implantation [4]. Herein, we report a rare case of BIA-ALCL, the first from Turkey.

A 40-year-old Caucasian female presented to our clinic with right-sided breast swelling and asymmetry. Five years ago, she was diagnosed with left-sided invasive ductal carcinoma. She received neoadjuvant chemotherapy, followed by mastectomy and axillary lymph node dissection of the left side and nipplesparing mastectomy of the right side. Macro-textured anatomical silicone gel implants and fat grafting were applied, followed by adjuvant chemotherapy. Five years later, breast ultrasound and MRI revealed effusion in the fibrous capsule surrounding the breast implant (Figures 1A and 1B). Initial evaluation of the effusion was benign and the implant was replaced by another one after partial capsulectomy. However, the seroma recurred. In the third sampling, the immunochemical analysis revealed typically large and pleomorphic CD30-positive so-called hallmark cells (Figures 1C and 1D). She was diagnosed with BIA-ALCL. The Ann Arbor stage was IE and the TNM stage was IA. Complete excision of the breast implant and capsule was performed and no capsule invasion was reported upon pathological evaluation. Neither further surgery nor chemotherapy was applied. She has remained in remission to date, at the $18^{\text {th }}$ month after the surgery.

Although it is a very rare entity, detection and diagnosis of BIA-ALCL is an emerging topic. BIA-ALCL is surgically treated and it has an indolent course, with the risk of death being 0.4 micromorts per patient [5]. Most cases are unilateral; however, rare bilateral cases have been reported. Patients mainly present with malignant effusions associated with the fibrous capsule surrounding the implants [6]. Lack of ALK expression and strong membranous expression of CD30 constitute the main immunochemical profile. The largest series published in the literature are summarized in Table 1.

The pathogenesis of BI-ALCL is still unclear. Textured implants are likely to induce a marked local T-cell immune response compared to smooth implants. Textured implants are known 
to shed silicone particulate. Macrophages digesting silicone particulate form foamy cells and release cytokines, eliciting T-cell chemotaxis and replication. These findings help us to hypothesize that $\mathrm{BI}-\mathrm{ALCL}$ originates from aberrant reactive T-cell populations [7]. The main treatment is surgical removal of the implant and total capsulectomy with complete excision of any associated mass until reaching negative margins on final pathologic evaluation, defined as complete surgical excision. Removal of the contralateral breast implant is controversial, as bilateral capsule involvement was reported in the literature $[6,8]$. Although there is no randomized controlled trial managing patients with incomplete capsulectomy, with residual
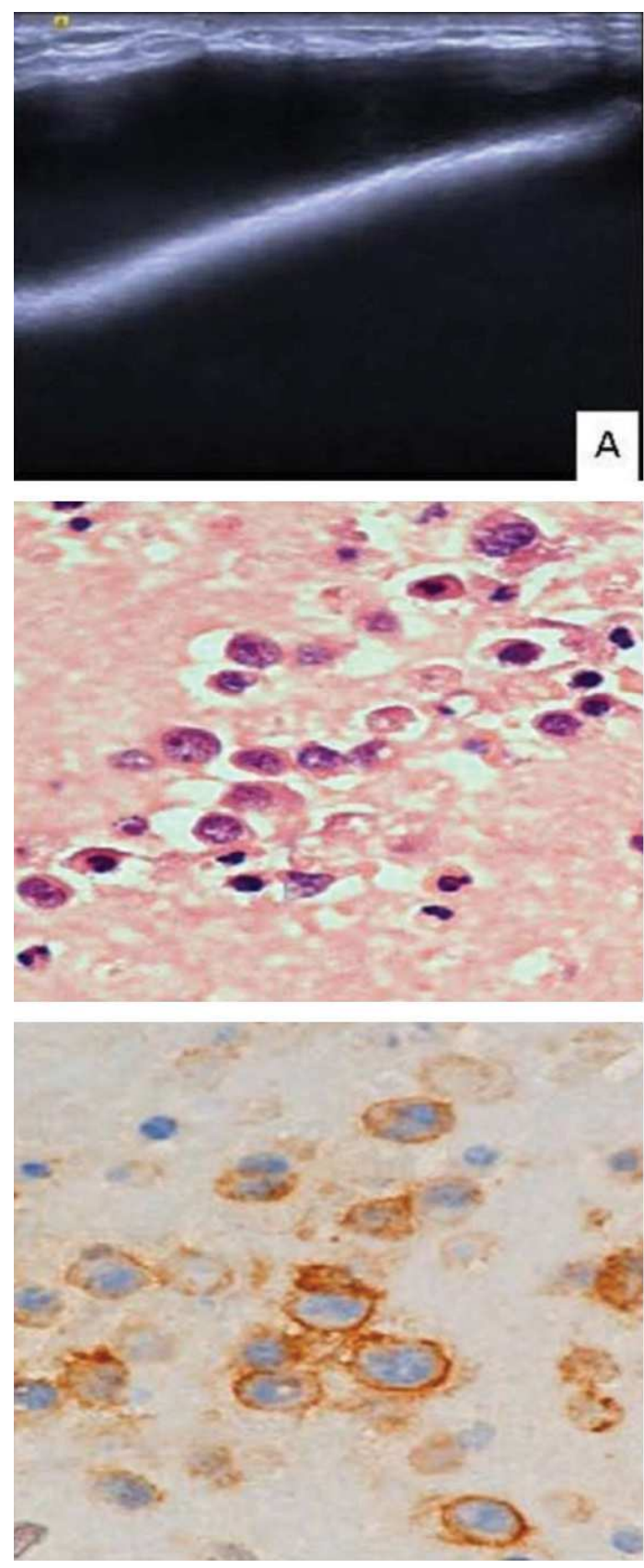

disease and with stage II-IV disease, the postulated approach is chemotherapy with cyclophosphamide, doxorubicin, vincristine, and prednisone (CHOP) [6]. CHOP plus etoposide and brentuximab vedotin are alternatives for ALCL treatment [7].

Our patient's diagnosis was based on CD30 positivity and the presence of large pleomorphic cells. Immunohistochemical staining for ALK was not performed and this is a limitation of our report. Immunohistochemical evaluation of the expressions of CD2, CD3, CD4, CD5, CD7, CD8, CD30, and ALK is necessary and constitutes a widely accepted strategy to evaluate seroma samples.
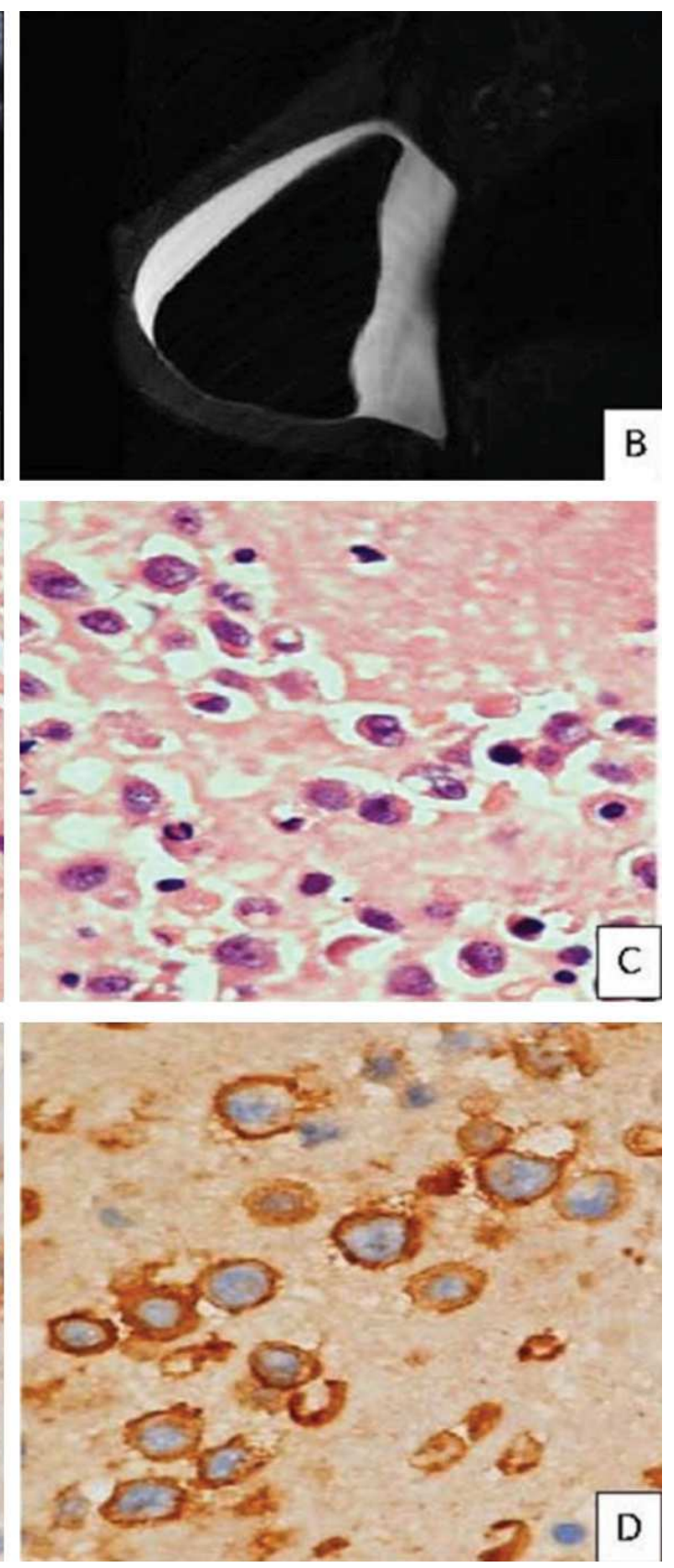

Figure 1. A\&B: Ultrasound (A) and magnetic resonance imaging (B) of the capsule of the implant and the seroma at breast. C: Hematoxylin eosin staining, large cells, pleomorphic cells with abundant cytoplasm. D: CD30 (+) lymphocytes. 


\begin{tabular}{|c|c|c|c|c|c|}
\hline Study & $\mathbf{n}$ & Age & $\begin{array}{l}\text { Interval from } \\
\text { implant to } \\
\text { diagnosis }\end{array}$ & $\begin{array}{l}\text { Implant } \\
\text { characteristics }\end{array}$ & Treatment and outcome \\
\hline Doren et al. [9] & 100 & $\begin{array}{l}\text { Mean } \\
53.2 \pm 12.3 \\
\text { years }\end{array}$ & $\begin{array}{l}\text { Mean } 10.7 \pm 4.6 \\
\text { years }\end{array}$ & $\begin{array}{l}\text { Textured }(n=51) \\
\text { Smooth }(n=0) \\
\text { Unknown }(n=49)\end{array}$ & No data available. \\
\hline $\begin{array}{l}\text { Loch-Wilkinson } \\
\text { et al. [10] }\end{array}$ & 55 & $\begin{array}{l}\text { Median } \\
47.1 \text { years }\end{array}$ & $\begin{array}{l}\text { Median } 7.46 \\
\text { years }\end{array}$ & $\begin{array}{l}\text { Biocell }(n=44) \\
\text { Polyurethane } \\
(n=15) \\
\text { Salt loss }(n=5) \\
\text { Siltex }(n=5) \\
\text { Poly Implant } \\
\text { Prothèse }(n=2) \\
\text { Smooth }(n=4)\end{array}$ & $\begin{array}{l}\text { All patients underwent total capsulectomy and removal of } \\
\text { implants on both the diseased and non-diseased sides. } \\
\text { Twelve patients had evidence of tumor infiltrating the } \\
\text { capsule. } \\
\text { Nine patients had adjuvant chemoradiotherapy, } 1 \text { patient had } \\
\text { adjuvant chemotherapy; } 5 \text { of them had local recurrence. Two } \\
\text { had positive tumor margins in histopathology. Three patients } \\
\text { survived and remained disease-free. } \\
\text { One patient received neoadjuvant chemotherapy. } \\
\text { One patient had autologous bone marrow transplant. } \\
\text { Overall, } 1 \text { patient who presented with seroma and } 3 \text { patients } \\
\text { who presented with mass and/or metastatic disease died. }\end{array}$ \\
\hline $\begin{array}{l}\text { de Boer at al. } \\
{[11]}\end{array}$ & 32 & $\begin{array}{l}\text { Median } 59 \\
\text { years }\end{array}$ & $\begin{array}{l}\text { Median } 13 \\
\text { years }\end{array}$ & $\begin{array}{l}\text { Macro-textured } \\
(\mathrm{n}=23) \\
\text { Micro-textured } \\
(\mathrm{n}=5) \\
\text { Unknown }(\mathrm{n}=4)\end{array}$ & $\begin{array}{l}\text { Surgery only }(n=11) \text {. } \\
\text { Neoadjuvant chemotherapy }(n=2) \text {. } \\
\text { Neoadjuvant chemoradiotherapy }(n=1) \text {. } \\
\text { Adjuvant radiotherapy }(n=2) . \\
\text { Adjuvant chemotherapy }(n=9) . \\
\text { Adjuvant chemoradiotherapy }(n=6) \text {. } \\
\text { Chemotherapy only }(n=1) \text {. } \\
\text { Autologous stem cell transplantation performed for } 5 \\
\text { patients. } \\
\text { Twenty-nine patients were in complete remission after first- } \\
\text { line }(n=23) \text { or second-line }(n=6) \text { treatment. Two patients died } \\
\text { of disseminated disease after second-line treatment. }\end{array}$ \\
\hline $\begin{array}{l}\text { Campanale et } \\
\text { al. [12] }\end{array}$ & 22 & $\begin{array}{l}\text { Mean } 49.6 \\
\text { years }\end{array}$ & Mean 7.8 years & $\begin{array}{l}\text { Textured surface } \\
\text { and silicone filler } \\
\text { device }(n=21) \\
\text { Textured surface } \\
\text { and a double lumen } \\
\text { saline/silicone filler } \\
\text { device }(n=1)\end{array}$ & $\begin{array}{l}\text { Implant removal with total capsulectomy only }(n=14) \text {. } \\
\text { Adjuvant chemotherapy and autologous stem cell } \\
\text { transplantation }(n=2) \text {. } \\
\text { Adjuvant chemotherapy + anti-CD30 }(n=1) \text {. } \\
\text { Adjuvant chemotherapy }(n=3) . \\
\text { Adjuvant chemoradiotherapy }(n=1) . \\
\text { Mastectomy and chemotherapy }(n=1) . \\
\text { Nineteen patients are apparently free of disease, } 1 \text { patient } \\
\text { died, and } 2 \text { are still undergoing chemotherapy. }\end{array}$ \\
\hline
\end{tabular}

As the number of breast implant surgeries is rising continuously, the diagnosis of BIA-ALCL is increasing. Patients undergoing breast implantation should be informed of the risk of lymphoma development. Recurring effusions around the capsule may reveal the suspicion of BIA-ALCL. Patients should be treated with surgery-based treatments. Randomized controlled studies are needed to determine standard chemotherapy protocols.

Keywords: Breast implants, Lymphoma, Large-cell, Anaplastic, Seroma

Anahtar Sözcükler: Meme implantı, Lenfoma, Büyük hücreli, Anaplastik, Seroma
Conflict of Interest: The authors of this paper have no conflicts of interest, including specific financial interests, relationships, and/or affiliations relevant to the subject matter or materials included.

\section{References}

1. Swerdlow SH, Campo E, Pileri SA, Harris NL, Stein H, Siebert R, Advani R, Ghielmini M, Salles GA, Zelenetz AD, Jaffe ES. The 2016 revision of the World Health Organization classification of lymphoid neoplasms. Blood 2016;127:2375-2390.

2. Food and Drug Administration. Medical Device Reports of Breast Implant-Associated Anaplastic Large Cell Lymphoma. Silver Spring, FDA, 2018. Available at https://www.fda.gov/MedicalDevices/ ProductsandMedicalProcedures/ImplantsandProsthetics/BreastImplants/ ucm481899.htm. 
3. de Jong $D$, Vasmel WL, de Boer JP, Verhave G, Barbe $E$, Casparie MK, van Leeuwen FE. Anaplastic large-cell lymphoma in women with breast implants. JAMA 2008;300:2030-2035.

4. Bizjak M, Selmi C, Praprotnik S, Bruck O, Perricone C, Ehrenfeld M, Shoenfeld Y. Silicone implants and lymphoma: the role of inflammation. J Autoimmun 2015;65:64-73.

5. Sieber DA, Adams WP Jr. What's your micromort? A patient-oriented analysis of breast implant-associated anaplastic large cell lymphoma (BIAALCL). Aesthet Surg J 2017;37:887-891.

6. Clemens MW, Medeiros $\sqcup$, Butler CE, Hunt KK, Fanale MA, Horwitz $\mathrm{S}$, Weisenburger DD, Liu J, Morgan EA, Kanagal-Shamanna R, Parkash V, Ning J, Sohani AR, Ferry JA, Mehta-Shah N, Dogan A, Liu H, Thormann N, Di Napoli A, Lade S, Piccolini J, Reyes R, Williams T, McCarthy CM, Hanson SE, Nastoupil $\amalg$, Gaur R, Oki Y, Young KH, Miranda RN. Complete surgical excision is essential for the management of patients with breast implantassociated anaplastic large-cell lymphoma. J Clin Oncol 2016;34:160-168.

7. Mehta-Shah N, Clemens MW, Horwitz SM. How I treat breast implantassociated anaplastic large cell lymphoma. Blood 2018;132:1889-1898.

8. Bautista-Quach MA, Nademanee A, Weisenburger DD, Chen W, Kim YS. Implant-associated primary anaplastic large-cell lymphoma with simultaneous involvement of bilateral breast capsules. Clin Breast Cancer 2013;13:492-495.

9. Doren EL, Miranda RN, Selber JC, Garvey PB, Liu J, Medeiros L, Butler CE, Clemens MW. U.S. epidemiology of breast implant-associated anaplastic large cell lymphoma. Plast Reconstr Surg 2017;139:1042-1050.

10. Loch-Wilkinson A, Beath KJ, Knight RJW, Wessels WLF, Magnusson M, Papadopoulos T, Connell T, Lofts J, Locke M, Hopper I, Cooter R, Vickery K, Joshi PA, Prince HM, Deva AK. Breast implant-associated anaplastic large cell lymphoma in Australia and New Zealand: high-surface-area textured implants are associated with increased risk. Plast Reconstr Surg 2017;140:645-654.

11. de Boer $M$, van Leeuwen FE, Hauptmann $M$, Overbeek LIH, de Boer JP, Hijmering NJ, Sernee A, Klazen CAH, Lobbes MBI, van der Hulst R, Rakhorst $H A$, de Jong D. Breast implants and the risk of anaplastic large-cell lymphoma in the breast. JAMA Oncol 2018;4:335-341.

12. Campanale A, Boldrini R, Marletta M. 22 cases of breast implant-associated ALCL: awareness and outcome tracking from the Italian Ministry of Health. Plast Reconstr Surg 2018;141:11-19.

\title{
A Rare Cause of Cyanosis Since Birth: Hb M-Iwate
}

\section{Doğumdan Itibaren Mevcut Olan Siyanozun Nadir Bir Nedeni: Hb M-Iwate}

\author{
(1) Birgül Mutlu1, (1) Ebru Yılmaz Keskin22, (1) Ana Catarina Oliveira3, (1) Luis Relvas4, (1) Celeste Bento5 \\ ${ }_{1}^{1}$ Doruk Yıldırım Hospital, Clinic of Neonatal Intensive Care, Bursa, Turkey \\ 2Süleyman Demirel University Faculty of Medicine, Department of Pediatric Hematology and Oncology, Isparta, Turkey \\ ${ }^{3}$ Centro Hospitalar e Universitário de Coimbra, Clinic of Hematology, Coimbra, Portugal
}

\section{To the Editor,}

Cyanosis in an apparently healthy newborn baby may be caused by hemoglobin $(\mathrm{Hb})$ variants associated with the formation of methemoglobin. Such $\mathrm{Hb}$ variants are collectively known as $\mathrm{M}$ Hbs [1]. Hb M-Iwate [alpha2 87(F8) His>Tyr, HBA2:c.262C>T] is one of the $\mathrm{Hb}$ variants associated with methemoglobinemia [2].

Many $\mathrm{Hb}$ variants have been reported so far from Turkey $[3,4,5]$. We report herein a newborn baby from Bursa, Turkey, with methemoglobinemia and (pseudo) cyanosis having $\mathrm{Hb} \mathrm{M}$-Iwate as the underlying cause. To our knowledge, this is only the second report of $\mathrm{Hb} \mathrm{M}$-Iwate from Turkey, and more than four decades have passed since its first observation in Turkey in a 21-year-old male by Ozsoylu [6]. In addition, our case represents the first case of $\mathrm{Hb} \mathrm{M}$-Iwate from Turkey identified through genetic analysis of the $\alpha$-globin chain gene (HBA).
The boy, born at term to a 32-year-old mother, was noted to be cyanotic immediately after birth. He had findings of dyspnea and he received oxygen by hood.

In the family history, the mother had history of cyanosis, particularly in the peroral area, and was otherwise healthy. In addition, the maternal grandfather and his mother, who had migrated from Thessaloniki (Greece), also had a history of cyanosis.

The oxygen saturation $\left(\mathrm{SpO}_{2}\right)$ of the baby, measured by pulse oximeter, was between $50 \%$ and $60 \%$. Administration of oxygen did not result in an increase of the measured $\mathrm{SpO}_{2}$. In venous blood gas analysis, $\mathrm{pH}$ was $7.43, \mathrm{pCO}_{2}$ was 34.6 $\mathrm{mmHg}_{1} \mathrm{pO}_{2}$ was $45.3 \mathrm{mmHg}$, and the $\mathrm{p}_{50}$ value was $39.2 \mathrm{mmHg}$ (normal range: $22.6-29.4 \mathrm{mmHg}$ ). Methemoglobin relative concentration was 13.5\% (normal: <1.5\%). Complete blood 